\title{
UDC 502.36/.504.3.054:656.2
}

\author{
O. V. BERLOV ${ }^{1 *}$ \\ ${ }^{1 *}$ Dep. «Hydraulics and Water Supply», Dnipropetrovsk National University of Railway Transport named after Academician \\ V. Lazaryan, Lazaryan St., 2, Dnipropetrovsk, Ukraine, 49010, tel. +38 (056) 273 15 09, e-mail berlov@bigmir.net, \\ ORCID 0000-0002-7442-0548
}

\section{ATMOSPHERE PROTECTION IN CASE OF EMERGENCY DURING TRANSPORTATION OF DANGEROUS CARGO}

Purpose. The paper highlights the development of numerical models for prediction of atmospheric pollution in case of burning of the solid rocket propellant in a railway car, situated near the building on railway territory. These models can be used in predicting the effectiveness of neutralization upon the atmosphere protection for this type of accidents. Methodology. To solve this problem the numerical models based on the use of Navier-Stokes equations, to determine the velocity field of the wind flow near cars and buildings, and contaminants-transfer equations in the atmosphere were developed. For the numerical integration of pollutant transport equation was used implicit «change - triangle» difference scheme. When constructing a difference scheme physical and geometric cleavage of the transfer equation is carried out in four steps. Unknown value of pollutant concentration at each step of cleavage is determined by the explicit scheme - the method of «point-to-point computation». For the numerical integration of the Navier-Stokes equations are used implicit difference schemes. When carrying out computing experiment also takes into account: the velocity profile of wind flow; interaction between the building and the wind flow and flame jet of solid rocket propellant; the presence of a railroad car; inside which there is a source of pollution; instability of pollutant emissions. On the basis of constructed numerical models was performed the computer experiment for assessing the level of air pollution at dangerous cargo rail transportation in case of emergency at railway territory. The application calculations for the timely combustion products neutralization of solid rocket propellant were carried out. Findings. The numerical models that let promptly calculate air contamination in case of emergency during solid rocket propellant transportation, as well as calculate the rational parameters of pollutant neutralization process were developed by the researcher. These models can be used for routine calculations of various accident scenarios simulation. Originality. Numerical models were developed; they take into account significant factors, influencing the pollutant dispersion process in the atmosphere. On their base a pollutant neutralization method was offered in emergency situations on the railway transport. Practical value. Efficient numerical models, so called «diagnostic models» were considered for the rapid calculation of the air pollution level and air protection technology in emergency situations, in particular, in the case of railway transportation the solid rocket propellant.

Keywords: train accidents; air pollution; pollutant neutralization; numerical simulation

\section{Introduction}

Accidents during transportation of toxic chemicals, for example, solid rocket propellant (Fig.1) can intensively impact on the environment [2-4, 9].

In the case of this propellant burning the great amount of toxic chemicals are dispersed in atmosphere. So it is important to predict the atmosphere pollution in the case of the possible accident and develop methods to protect atmosphere from pollution (Fig. 2) [1, 11].

That is why the prediction of the atmosphere pollution in the case of the mighty emissions during transportation is of great interest.

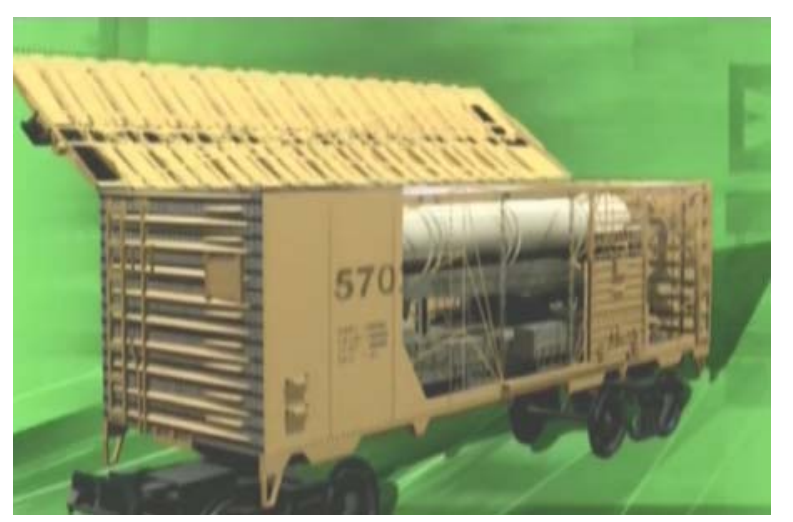

Fig. 1. Transport of solid rocket propellant in a railway wagon 


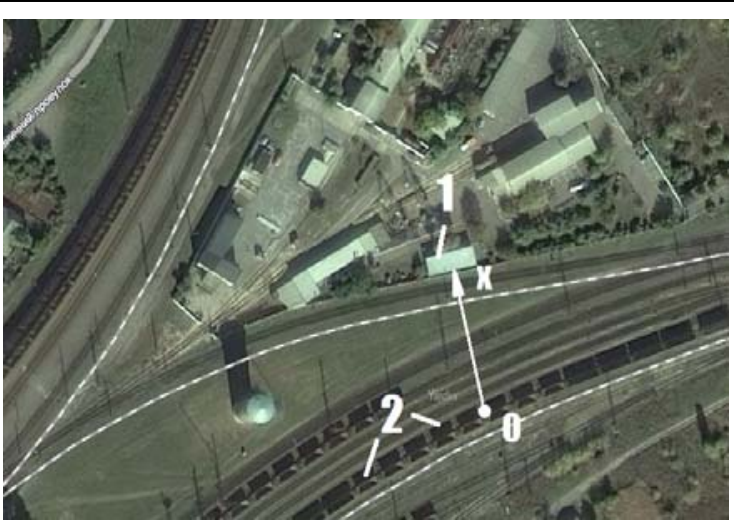

Fig. 2. General view of settlement areas: 1 - building on the territory of station «Pavlohrad-1», 2 - train

Nowadays to predict the dimensions of the hitting area in the case of outdoor toxic chemical release the special standard model is used in Ukraine [10]. This model is formed on the basis of some empirical models and it has a lot of lacks and is, without doubt, unrealistic. The model does not take into account the influence of the wind velocity and the atmosphere diffusion on the concentration dispersion in the atmosphere. The main lack of this model is that the standard model cannot calculate the change of toxic chemical concentration in the atmosphere after the accident. In some cases Gauss model is used to predict atmosphere pollution level $[5-7,13]$. It is very important to develop CFD (Computational Fluid Dynamics) models to solve the problem discussed $[1,8,14,15]$.

\section{Purpose}

The purpose of this work is the development of the numerical model to predict the atmosphere pollution in micro scale level in the case of solid propellant burning which also can be used to predict the effectiveness of neutralization for atmosphere protection for this type of accident.

\section{Methodology}

When the solid propellant burns different toxic chemicals are emitted in the atmosphere. To compute the toxic chemical (product of propellant burning) dispersion the Navier-Stokes equations and equation of mass transfer are used [14]:

$$
\frac{\partial \omega}{\partial t}+\frac{\partial u \omega}{\partial x}+\frac{\partial v \omega}{\partial y}=\frac{1}{\operatorname{Re}}\left(\frac{\partial^{2} \omega}{\partial x^{2}}+\frac{\partial^{2} \omega}{\partial y^{2}}\right)
$$

$$
\frac{\partial^{2} \psi}{\partial x^{2}}+\frac{\partial^{2} \psi}{\partial y^{2}}=-\omega
$$

where $\psi-$ is flow function; $\omega=\frac{\partial v}{\partial x}-\frac{\partial u}{\partial y}-$ is vorticity; $u=\frac{\partial \psi}{\partial y}, v=\frac{\partial \psi}{\partial x}$.

This model is used to predict the air pollution near railway car with solid rocket propellant (Fig.2).

To simulate the process of toxic chemical dispersion in the atmosphere (for the distance about $300 \mathrm{~m})$ the 2-D transport equation is used $[8,14]$ :

$$
\begin{aligned}
\frac{\partial C}{\partial t}+\frac{\partial u C}{\partial x}+\frac{\partial v C}{\partial y} & +\sigma C=\operatorname{div}(\mu \operatorname{grad} C)+ \\
& +\sum_{i=1}^{N} Q_{i}(t) \delta\left(x-x_{i}\right) \delta\left(y-y_{i}\right),
\end{aligned}
$$

where $C-$ is the concentration of toxic chemical; $u, v$ - are the velocity components in $x, y$ direction respectively; $\mu=\left(\mu_{x}, \mu_{y}\right)$ - are the coefficients of turbulent diffusion in $\mathrm{x}, \mathrm{y}$ direction respectively; $\sigma$ - is the parameter taking into account the process of toxic gas decay or rain wash out; $x_{i}, y_{i}$ - are the coordinates of point source of emission; $Q_{i}(t)$ - is the intensity of pollutant emission; $\delta\left(x-x_{i}\right) \delta\left(y-y_{i}\right)-$ is Dirac delta-function.

The boundary conditions for the governing equations are discussed in [14].

In the developed numerical model, the following profile of velocity component $u$ and coefficient of diffusion is used $[5,6]$ :

$$
u=u_{1}\left(\frac{y}{y_{1}}\right)^{p}, \mu_{y}=k_{1}\left(\frac{y}{y_{1}}\right)^{m}, \mu_{x}=k_{0} u,
$$

where $u_{1}$ - is the velocity at height $y_{1} ; k_{1}=0,2$; $k_{0}=0,1 ; p=0,16 ; m \approx 1$.

Numerical integration. To solve the governing equations the implicit difference schemes were used $[14,15]$. These are so called «change - triangle» difference schemes. 


\section{Findings}

To minimize the extent of contamination and the risk of toxic defeat people in case of emergency during transportation of solid rocket propellant it is proposed technology, aimed at localization of the source of emission of products of combustion solid rocket propellant. It is proposed to include in the train which transports solid rocket propellant, the car with the pump unit and tank with a stock of neutralizing solution. It is also proposed to include a buffer car between the rail car where solid propellant is transported and the car with the pump unit. This buffer truck will serve as a «screen» for the protection of the car with the pump unit from heat radiation of the combustion solid rocket propellant. With this technology, was organized rapid feed of neutralizing solution into the plume of combustion products and thereby minimizing time the free flow of products of combustion solid rocket propellant in the atmosphere. In addition, unlike the traditional scheme of feeding catalyst in the form of streams offered feed through the sprinkler, which is posted on pull-rod (Fig.3). This is because the temperature of the combustion solid rocket propellant in the atmosphere is high and if you use a traditional presentation in the form of a jet, there will be rapid evaporation of droplets of reagent on the path of its movement from the installation to the jet plume.

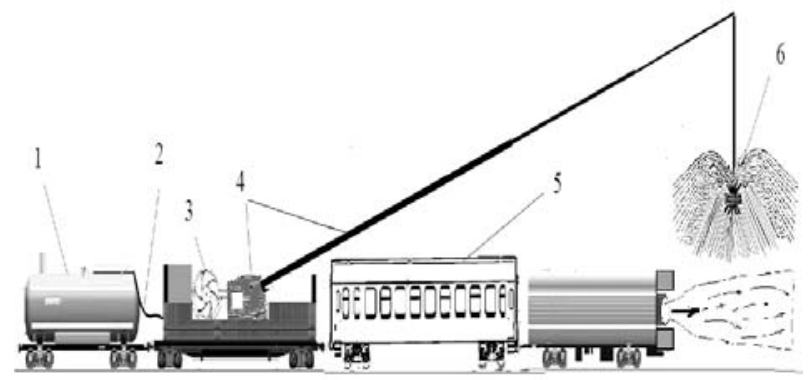

Fig. 3. Sketch of toxic chemical neutralization: 1 - vessel with the reagent, 2 - pipeline, 3 - pump, 4 -pop-arrow, 5 - buffer car, 6 - sprinkler

Problem setting - to evaluate the effectiveness of the process of neutralization of various intensities of reagent feed and placement of the sprinkler to the source of emission of hazardous substances.

The calculation is performed for the following tasks:
Scenario 1 - no neutralization;

Scenario 2 - supply of reagent is performed at a height of $13,5 \mathrm{~m}$ and at a distance of $20 \mathrm{~m}$ from the source of emission. This distance is constant in all scenarios, catalyst feed rate of $1 \mathrm{~kg} / \mathrm{s}$;

Scenario 3 - the reagent feed is done at the height of $13,5 \mathrm{~m}$, catalyst feed rate of $8 \mathrm{~kg} / \mathrm{s}$.

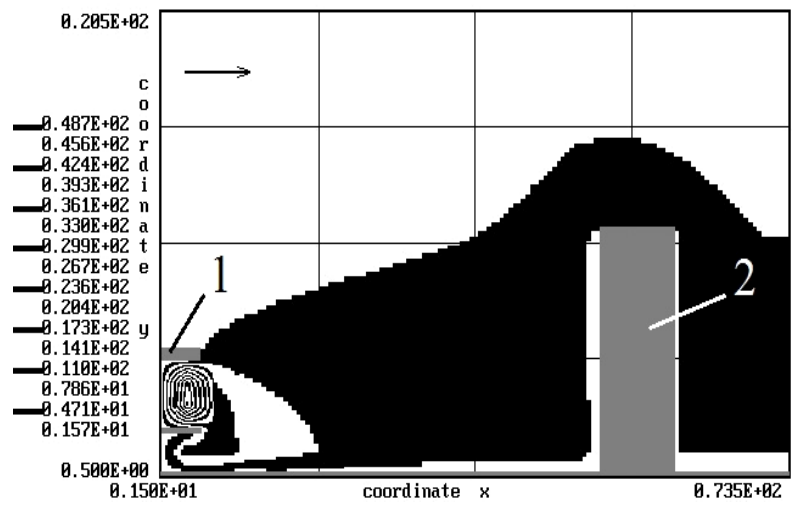

Fig. 4. Concentration contours of $\mathrm{HCl}$ (no reagent supply, $\mathrm{t}=120 \mathrm{sec}$ ): 1 - car with solid rocket propellant, 2 - building near railway station

On the base of the developed numerical models the special codes were developed. Some results of their application are shown in Fig.4-6.

The subsequent figures illustrate the area of atmospheric pollution in the case of the options considered. The first figure (Fig. 4) corresponds to the situation when there is no flow of reagent and compares the efficiency of neutralization for each option, comparing to the area of contamination with this picture.

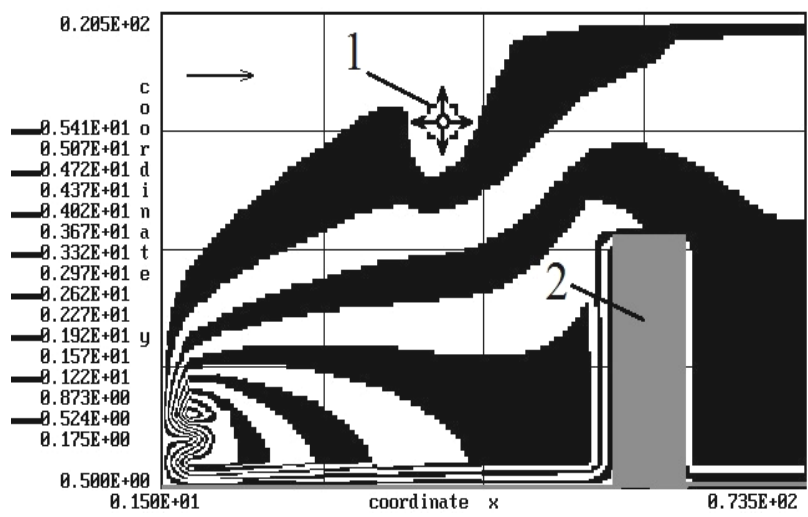

Fig. 5. Concentration contours of $\mathrm{HCl}$ (reagent supply, $\mathrm{t}$ $=120 \mathrm{sec}$, Scenario 2: the height of the feed catalyst $13,5 \mathrm{~m}$, flow rate $1 \mathrm{~kg} / \mathrm{s}$ ): 1 - sprinkler; 2 - building 


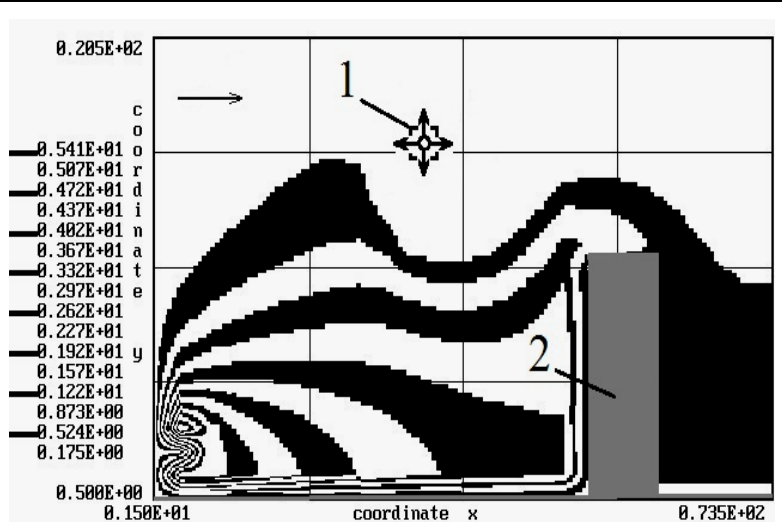

Fig. 6. Concentration contours of $\mathrm{HCl}$ (reagent supply, $\mathrm{t}$ $=120 \mathrm{sec}$, Scenario 3: the height of the feed catalyst $13,5 \mathrm{~m}$, flow rate $8 \mathrm{~kg} / \mathrm{s})$ :

1 - sprinkler; 2 - building

Results of neutralization effectiveness are shown in Tabl.1, 2.

Table 1

The efficiency of neutralization (scenario 2)

\begin{tabular}{c|c|c|c}
\hline $\mathrm{t}$ & 45 сек & 75 сек & 120 сек \\
\hline $\begin{array}{c}\text { The efficiency of } \\
\text { neutralization }\end{array}$ & $6,8 \%$ & $8,2 \%$ & $8,9 \%$
\end{tabular}

Table 2

The efficiency of neutralization (scenario 3)

\begin{tabular}{c|c|c|c}
\hline $\mathrm{t}$ & 45 сек & 75 сек & 120 сек \\
\hline $\begin{array}{c}\text { The efficiency of } \\
\text { neutralization }\end{array}$ & $50 \%$ & $62 \%$ & $69 \%$
\end{tabular}

Results from Tabl.1, 2 show that the rate of reagent strongly influences the effectiveness of protection. Also it is clear from Fig.5, 6 that the height of reagent supply is too high because the region near the railway car and building is still in the plume of toxic chemical.

\section{Originality and practical value}

A new numerical model to predict atmosphere pollution and neutralization of toxic chemical after accidents at railways was developed. The model is based on the 2-D transport equation. The developed model takes into account wind profile, diffusion, emission rate. This model allows evaluating the level of atmosphere pollution and effectiveness of neutralization. The model can be useful in the field of transport routes safety prediction.

\section{Conclusions}

The article contains results of numerical simulation of air pollution near «Pavlohrad-1» station after the accident at railway. To simulate the process of air pollution the 2-D developed numerical model was used. The developed numerical model takes into account the main physical processes which influences the pollutant dispersion in atmosphere. The developed models allow simulating the process of neutralization of toxic chemical in atmosphere. The future work in this field will be connected with development of fluid dynamics models to simulate the pollutant dispersion over the complex terrain.

\section{LIST OF REFERENCE LINKS}

1. Беляев, Н. Н. Математическое моделирование в задачах экологической безопасности и мониторинга чрезвычайных ситуаций : монография / Н. Н. Беляев, Е. Ю. Гунько, П. Б. Машихина. - Днепропетровск : Акцент ПП, 2013. $-159 \mathrm{c}$.

2. Беляев, Н. Н. Прогнозирование загрязнения приземного слоя атмосферы при горении твердого ракетного топлива в хранилище / Н. Н. Беляев, А. В. Берлов // Зб. наук. пр. НГУ. - Дніпропетровськ, 2013. - № 42. - С. 160-167.

3. Беляев, Н. Н. Моделирование аварийного загрязнения атмосферы при чрезвычайной ситуации в хранилище твердого ракетного топлива / Н. Н. Беляев, А. В. Берлов, А. В. Шевченко // Наука та прогрес транспорту. - 2014. № 5 (53). - C. 29-38. doi: 10.15802/stp2014/29973.

4. Берлов, А. В. Расчет загрязнения приземного слоя атмосферы при горении твердого ракетного топлива / А. В. Берлов // Наук. Вісн. будва : зб. наук. пр. / Харк. нац. ун-т буд-ва та архіт. - Харків, 2014. - №1 (75). - С. 185-189.

5. Берлянд, М. Е. Прогноз и регулирование загрязнения атмосферы / М. Е. Берлянд. - Ленинград : Гидрометеоиздат, 1985. - 273 с.

6. Бруяцкий, Е. В. Теория атмосферной диффузии радиоактивных выбросов / Е. В. Бруяцкий. Киев : Институт гидромеханики НАН Украины, 2000. -443 с.

7. Гусев, Н. Г. Радиоактивные выбросы в биосфеpe / Н. Г. Гусев, В. А. Беляев. - Москва : Энергоатомиздат, 1991. -257 с. 
8. Марчук, Г. И. Математическое моделирование в проблеме окружающей среды / Г. И. Марчук. - Москва : Наука, 1982. - 320 с.

9. Машихина, П. Б. Моделирование распространения примеси в атмосфере с учетом рельефа местности / П. Б. Машихина // Вісн. Дніпропетр. нац. ун-ту залізн. трансп. ім. акад. В. Лазаряна. - Дніпропетровськ, 2009. - Вип. 27. С. $138-142$.

10. Методика прогнозування наслідків виливу (викиду) небезпечних хімічних речовин при аваріях на промислових об'єктах і транспорті. Київ, 2001. - 33 с.

11. Моделирование аварийных ситуаций на промышленных объектах и безопасность жизнедеятельности / Л. И. Антошкина, Н. Н. Беляев, Л. Ф. Долина, Е. Д. Коренюк. - Дніпропетровськ : Нова ідеологія, 2011. - 123 с.
12. Самарский, А. А. Теория разностных схем / А. А. Самарский. - Москва : Наука, 1983. $616 \mathrm{c}$.

13. Уорк, К. Загрязнение воздуха. Источники и контроль / К. Уорк, С. Уорнер - Москва : Мир, 1980. - 539 с.

14. Численное моделирование распространения загрязнения в окружающей среде / М. З. Згуровский, В. В. Скопецкий, В. К. Хрущ, Н. Н. Беляев. - Київ : Наук. думка, 1997. - 368 с.

15. Biliaiev, M. Numerical Simulation of Indoor Air Pollution and Atmosphere Pollution for Regions Having Complex Topography / M. Biliaiev // NATO Science for Peace and Security Series C: Environmental Security. - 2012. - P. 87-91. doi: 10.1007/978-94-007-1359-8 15.

\title{
А. В. БЕРЛОВ ${ }^{1 *}$
}

\begin{abstract}
${ }^{1 *}$ Каф. «Гидравлика и водоснабжение», Днепропетровский национальный университет железнодорожного транспорта имени академика В. Лазаряна, ул. Лазаряна, 2, Днепропетровск, Украина, 49010, тел. +38 (056) 2731509 , эл. почта berlov@bigmir.net, ORCID 0000-0002-7442-0548
\end{abstract}

\section{ЗАЩИТА АТМОСФЕРЫ В СЛУЧАЕ АВАРИИ ПРИ ТРАНСПОРТИРОВКЕ ОПАСНЫХ ГРУЗОВ}

Цель. Работа посвящена разработке численных моделей для прогноза загрязнения атмосферы при горении твердого ракетного топлива в железнодорожном вагоне, расположенном вблизи здания на примагистральной территории. Данные модели могут быть использованы при прогнозировании эффективности нейтрализации по защите атмосферы для этого типа аварий. Методика. Для решения поставленной задачи разработаны численные модели, основанные на применении уравнений Навье-Стокса, для определения поля скорости ветрового потока вблизи вагонов и зданий, и уравнении переноса примеси в атмосфере. Для численного интегрирования уравнения транспорта загрязнителя использовалась неявная попеременно-треугольная разностная схема. При построении разностной схемы осуществляется физическое и геометрическое расщепление уравнения переноса на четыре шага. Неизвестное значение концентрации загрязнителя на каждом шаге расщепления определяется по явной схеме - методу «бегущего счета». Для численного интегрирования уравнений Навье-Стокса применяются неявные разностные схемы. При проведении вычислительного эксперимента также учитываются: профиль скорости ветрового потока; взаимодействие ветрового потока со зданием и струей продуктов горения твердого ракетного топлива; наличие железнодорожного вагона, внутри которого находится источник загрязнения; нестационарность эмиссии загрязнителя. На основе построенных численных моделей проведен вычислительный эксперимент по оценке уровня загрязнения атмосферы при транспортировке железнодорожным транспортом опасного груза в случае аварии на примагистральной территории. Проведены расчеты по применению своевременной нейтрализации продуктов горения твердого ракетного топлива. Результаты. Исследователем разработаны численные модели, которые позволяют оперативно рассчитать загрязнение атмосферы в случае аварии при транспортировке твердого ракетного топлива, а также рациональные параметры процесса нейтрализации загрязнителя. Эти модели могут использоваться для серийных расчетов по моделированию различных сценариев аварийных ситуаций. Научная новизна. Разработаны численные модели, позволяющие учесть существенные факторы, влияющие на процесс рассеивания загрязняющих веществ в атмосфере и предложена на их базе методика нейтрализации загрязнителя при чрезвычайных ситуациях на железнодорожном транспорте. Практическая значимость. Рассмотрены эффективные численные модели «diagnostic models» для экспресс-расчета уровня загрязнения атмосферы и разработана технология защиты 
атмосферы при аварийных ситуациях, в частности, в случае перевозки железнодорожным транспортом твердого ракетного топлива.

Ключевые слова: аварии на железнодорожном транспорте; загрязнение атмосферы; нейтрализация загрязнителя; численное моделирование

\title{
О. В. БЕРЛОВ ${ }^{1 *}$
}

\author{
${ }^{1 *}$ Каф. «Гідравліка та водопостачання», Дніпропетровський національний університет залізничного транспорту \\ імені академіка В. Лазаряна, вул. Лазаряна 2, Дніпропетровськ, Україна, 49010, тел. +38 (056) 2731509 , \\ ел. пошта berlov@bigmir.net, ORCID 0000-0002-7442-0548
}

\section{ЗАХИСТ АТМОСФЕРИ У ВИПАДКУ АВАРІЇ ПРИ ТРАНСПОРТУВАННІ НЕБЕЗПЕЧНИХ ВАНТАЖІВ}

Мета. Робота присвячена розробці чисельних моделей для прогнозу забруднення атмосфери при горінні твердого ракетного палива в залізничному вагоні, розташованому поблизу будівлі на примагістральній території. Дані моделі можуть бути використані при прогнозуванні ефективності нейтралізації по захисту атмосфери для цього типу аварій. Методика. Для розв'язання поставленої задачі розроблені чисельні моделі, засновані на застосуванні рівнянь Нав'є-Стокса, для визначення поля швидкості вітрового потоку поблизу вагонів і будівель, та рівнянні переносу домішки в атмосфері. Для чисельного інтегрування рівняння транспорту забруднювача використовувалася неявна поперемінно-трикутна різницева схема. При побудові різницевої схеми здійснюється фізичне і геометричне розщеплення рівняння переносу на чотири кроки. Невідоме значення концентрації забруднювача на кожному кроці розщеплення визначається за явною схемою - методу «біжучого рахунку». Для чисельного інтегрування рівнянь Нав'є-Стокса застосовуються неявні різницеві схеми. При проведенні обчислювального експерименту також враховуються: профіль швидкості вітрового потоку; взаємодія вітрового потоку з будівлею і струменем продуктів горіння твердого ракетного палива; наявність залізничного вагона, усередині якого знаходиться джерело забруднення; нестаціонарність емісії забруднювача. На основі побудованих чисельних моделей проведено обчислювальний експеримент із оцінки рівня забруднення атмосфери при транспортуванні залізничним транспортом небезпечного вантажу при аварії на примагістральній території. Проведено розрахунки по застосуванню своєчасної нейтралізації продуктів горіння твердого ракетного палива. Результати. Дослідником розроблено чисельні моделі, які дозволяють оперативно розрахувати забруднення атмосфери в разі аварії при транспортуванні твердого ракетного палива, а також раціональні параметри нейтралізації забруднювача. Ці моделі можуть використовуватись для серійних розрахунків різноманітних сценаріїв аварійних ситуацій. Наукова новизна. Розроблено чисельні моделі, що дозволяють врахувати істотні фактори, що впливають на процес розсіювання забруднюючих речовин у атмосфері та запропонована на їх базі методика нейтралізації забруднювача при надзвичайних ситуаціях на залізничному транспорті. Практична значимість. Розглянуто ефективні чисельні моделі «diagnostic models» для експрес-розрахунку рівня забруднення атмосфери та розроблено технологію захисту атмосфери при аварійних ситуаціях, зокрема, у разі перевезення залізничним транспортом твердого ракетного палива.

Ключові слова: аварії на залізничному транспорті; забруднення атмосфери; нейтралізація забруднювача; чисельне моделювання

\section{REFERENCES}

1. Belyayev N.N., Gunko Ye.Yu., Mashikhina P.B. Matematicheskoye modelirovaniye v zadachakh ekologicheskoy bezopasnosti i monitoringa chrezvychaynykh situatsiy [Mathematical modeling in problems of environmental safety and monitoring emergencies]. Dnepropetrovsk, Aktsent PP Publ., 2013, 159 p.

2. Belyayev N.N., Berlov A.V. Prognozirovaniye zagryazneniya prizemnogo sloya atmosfery pri gorenii tverdogo raketnogo topliva $\mathrm{v}$ khranilishche [Prediction of pollution in the atmospheric surface layer during combustion of solid rocket fuel in storage]. Zbirnyk naukovykh prats NHU [Proc of NMU]. Dnipropetrovsk, Natsionalnyi Hirnychyi Universytet Publ., 2013, no. 42, pp. 160-167

3. Belyayev N.N., Berlov A.V., Shevchenko A.V. Modelirovaniye avariynogo zagryazneniya atmosfery pri chrezvychaynoy situatsii $v$ khranilishche tverdogo raketnogo topliva [Simulation of the accidental pollution af- 
ter the emergency in to the storage of rocket solid propellant]. Nauka ta prohres transport - Science and Transport Progress, 2014, no. 5 (53), pp. 29-38. doi: 10.15802/stp2014/29973.

4. Berlov A.V. Raschet zagryazneniya prizemnogo sloya atmosfery pri gorenii tverdogo raketnogo topliva [Calculation of the pollution of the ground atmospheric layer during combustion of solid rocket fuel]. Naukovyi visnyk budivnytstva: zbirnyk naukovykh prats [Proc. of «Scientific Bulletin of construction»], 2014, no. 1 (75), pp.185-189.

5. Berlyand M.Ye. Prognoz i regulirovaniye zagryazneniya atmosfery [Prediction and regulation of air pollution]. Leningrad, Gidrometeoizdat Publ., 1985. 273 p.

6. Bruyatskiy Ye.V. Teoriya atmosfernoy diffuzii radioaktivnykh vybrosov [The theory of atmospheric diffusion of radioactive emissions]. Kiev, Institut gidromekhaniki NAN Ukrainy Publ., 2000. 443 p.

7. Gusev N.G., Belyaev V.A. Radioaktivnyye vybrosy v biosfere [Radioactive emissions in the biosphere]. Moscow, Energoatomizdat Publ., 1991. 257 p.

8. Marchuk G.I. Matematicheskoye modelirovaniye v probleme okruzhayushchey sredy [Mathematical modeling in the environmental problem]. Moscow, Nauka Publ., 1982. 320 p..

9. Mashikhina P.B. Modelirovaniye rasprostraneniya primesi v atmosfere s uchetom relefa mestnosti [The distribution modeling of impurities in the atmosphere with taking into account of terrain]. Visnyk Dnipropetrovskoho natsionalnoho universytetu zaliznychnoho transportu imeni akademika V. Lazariana [Bulletin of Dnipropetrovsk National University of Railway Transport named after Academician V. Lazaryan], 2009, issue 27, pp. 138-142.

10. Metodyka prohnozuvannia naslidkiv vylyvu (vykydu) nebezpechnykh khimichnykh rechovyn pry avariiakh na promyslovykh obiektakh $i$ transporti [Methods of prediction the consequences of the spout (emission) of hazardous chemicals in accidents at industrial objects and transport]. Kyiv, 2001. 33 p.

11. Antoshkina L.I., Belyaev N.N., Dolina L.F., Korenyuk Ye.D. Modelirovaniye avariynykh situatsiy na promyshlennykh obektakh i bezopasnost zhiznedeyatelnosti [Simulation of emergency situations at industrial facilities and life safety]. Dnipropetrovsk, Nova ideolohiia Publ., 2011. 123 p.

12. Samarskiy A.A. Teoriya raznostnykh skhem [The theory of difference schemes]. Moscow, Nauka Publ., 1983. $616 \mathrm{p}$.

13. Uork, K., Uorner S. Zagryazneniye vozdukha. Istochniki i kontrol [Air pollution. Sources and control]. Moscow, Mir Publ., 1980. 539 p.

14. Zgurovskiy M.Z., Skopetskiy V.V., Khrushch V.K., Belyaev N.N. Chislennoye modelirovaniye rasprostraneniya zagryazneniya $v$ okruzhayushchey srede [Numerical modelling of pollution spreading in the environment]. Kyiv, Naukova dumka Publ., 1997. 368 p.

15. Biliaiev M. Numerical Simulation of Indoor Air Pollution and Atmosphere Pollution for Regions Having Complex Topography. NATO Science for Peace and Security Series C: Environmental Security, 2012, pp. 87-91. doi: 10.1007/978-94-007-1359-8_15.

Prof. S. A. Pichugov, Dr. Sc. (Phys.-Math.) (Ukraine); Prof. S. Z. Polishhuk, Dr. Sc. (Tech.) (Ukraine) recommended this article to be published

Accessed: Nov. 16, 2015

Received: Jan. 11, 2016 